Study of vertebral morphogenesis of cobia larvae ... (Afifah Nasukha)

\title{
STUDY OF VERTEBRAL MORPHOGENESIS OF COBIA LARVAE, (Rachycentron canadum) BY DOUBLE STAINING METHODS
}

\author{
Afifah Nasukha\#, Titiek Aslianti, and Agus Priyono \\ Research and Development Institute for Mariculture, Gondol, Bali
}

(Received: 3 July 2012; Accepted: 4 October 2012)

\begin{abstract}
Vertebral development is one of the main indicators of organism growth. The aim of this study was to know the vertebral development of cobia Rachycentron canadum in larval stage (20 day post hatch). Vertebral assay was done with double staining methods. The result showed that cobia larvae from $0 \mathrm{dph}$ up to $5 \mathrm{dph}$ did not have cartilage. On $5 \mathrm{dph}$ up to $10 \mathrm{dph}$ had pre cartilage phase composed by calcium and on $10 \mathrm{dph}$ up to $18 \mathrm{dph}$ were cartilage phase and marked with blue color by alcian blue. Vertebral was formed perfectly as bones on $18 \mathrm{dph}$ marked with red color by alizarin red. On $20 \mathrm{dph}$, cartilage had been fully transformed to bones, and the segment of vertebral was clearly formed. Measurement showed that length of cobia vertebrae was $20.20 \pm 3.90 \mathrm{~mm}$, vertebrae segment was $0.91 \pm 0.11 \mathrm{~mm}$ and number of vertebral segments were between 25- 26 segments.
\end{abstract}

KEYWORDS: cobia, morphogenesis, Rachycentron canadum, vertebrae

\section{INTRODUCTION}

Cobia is the only species in the family Rachycentridae. Remoras (Family Echeneidae) are their closest relatives. The scientific name for cobia is Rachycentron canadum, which is derived from two Geek words: rachis (vertebral column) and kentron (sharp point). This name refers to their 7-9 extremely sharp, retractable, dorsal spines (Anonymous, 2012).

Cobia is a pelagic fish that thrives worldwide in all tropical and temperate seas, including Taiwan, Vietnam, Texas, America, and Australia except for the eastern Pacific Ocean (Arnold et al., 2002). In the western Atlantic, cobia was found from Nova Scotia south to Argentina; in the eastern Atlantic from Morocco to South Africa; and in the western Pacific from Japan to Australia. Cobia prefer water temperatures between $20^{\circ} \mathrm{C}-30^{\circ} \mathrm{C}$; they migrate south to warmer waters during autumn and winter then journey back north when temperatures rise again in the spring (Kaiser \& Holt, 2005; Pyng Yeh et al., 2008).

Cobia has some advantages in breeding and grow- out culture, i.e. exhibiting very fast growth rates, commands high demands, and high prices in the market (Su et al., 2000). Fast growing is one of the main influential aspects on fish culture. It has been reported by Benetti et al. (2010) that cobia are weaned from 20- 25 day post hatch (dph) and got body weight about $1 \mathrm{~g}, 25 \mathrm{~g}$ in 40 dph (Santosa et al., 2009), 25- 30 $\mathrm{g}$ in 3 month (90 dph) and $500 \mathrm{~g}$ in 6 month culture (Saputra et al., 2010). Larval stage until consumption size $(4-6 \mathrm{~kg})$ could be reached in first year's with high feeding efficiency (Chou et al., 2001) and could reach broodtsock size $(8-10 \mathrm{~kg}$ ) in second year's cultures (Xan Le, 2005). Beside that, cobia is also easy adapted

\# Corresponding author. Research and Development Institute for Mariculture, Jl. Br. Gondol, Kec. Gerokgak, Kab. Buleleng, Kotak Pos 140, Singaraja, Bali 81101, Indonesia. Tel.: +62 36292278 E-mail address: info.gondol@gmail.com 
species in net cage, high resistant from parasites and high economics value are some reason that making cobia one of the best candidate on marine aquaculture (Sun et al., 2006).

Research and Development Institute of Mariculture Gondol, Bali started cobia's culture in Indonesia since 2004. The breeding technology has been developed and the results need more attentions particularly in breeding production. To obtain high quality and high survival rate of cobia seeds, need an integrated on larval rearing technology including feed management and water management (Priyono et al., 2006).

To improve larval rearing techniques, a good understanding of larval morphology, behavior, life feed and artificial diet requirements, and environmental conditions are fundamental (Liao et al., 2001). Vertebral development is being one of the indicators of seed quality (Aslianti, 2005a; Aslianti, 2005b). Larval morphogenesis could be detected by normal and steady of vertebral development. The deformity in vertebrae will affect larval performance, slow growth, stunt body, and further larval mortality to larvae. At the end, it could decrease seed price and inflict a loss to farmers (Zambonino et al., 2005).

The aim of this study was to get a basic knowledge on the morphogenetical pattern of cobia (Rachycentron canadum) especially on vertebral development and its relation to its fast growing character. This information was expected to support cobia larva rearing technology and grow- out culture.

\section{MATERIAL AND METHODS}

\section{Cobia Larval Rearing}

Cobia (Rachycentron canadum) eggs were obtained from natural spawning in finfish hatchery of Research and Development Institute of Mariculture Gondol, Bali. Prior to this study, high quality of eggs were selected with fertilizations degree $880 \%$ Three thousand selected cobia eggs were put into 3- fiber glass tank with $1 \mathrm{~m}^{3}$ water volume filled with seawater. A single air stone was positioned at the bottom center of each tank with gentle aeration during experiment. After 24 hours, the hatched egg samples were taken and the numbers of larvae were counted for hatching rate (\%). Cobia were reared from hatching day ( 0 day post hatch) till 20 (20 dph).
Cobia culture technique based was on cobia rearing protocol described by Priyono (2007). Feeding was started on $1 \mathrm{dph}$. Microalgae, Nannochloropsis sp. were added every morning to maintain density of 3- $5 \times 10^{6}$ cells/ $\mathrm{mL} /$ day in larval tank used for green water and feed of zooplankton. Rotifers and Artemia sp. were the main feeds of cobia larvae. Rotifer sp. were given on $2 \mathrm{dph}$ until $10 \mathrm{dph}$ with density started at 10 up to 15 cells/ mL/day. Artemia sp. were started to be given from 5 dph with density of 1 ind./mL/day and increased gradually until the end of larval rearing with density of 25 ind./ mL/ day. Artificial feeds were also given to larvae to complete in the nutritional requirements. Pellet with 200 $300 \mathrm{~mm}$ particle size were given at $2 \mathrm{~g} / \mathrm{m}^{3} /$ day to each tank from $10 \mathrm{dph}$ until the end of larval rearing ( $20 \mathrm{dph}$ ). The amount of pellet were increased gradually based on larval requirement. Water changing in rearing tank was started from $10 \mathrm{dph}$ with initial $20 \%$ of total water volume and gradually increased until $100 \%$ of total water volume until the end of this study.

\section{Sample Collection}

Ten percent formaldehyde $10 \%$ was prepared as preservative solution. Twenty larvae were randomly collected from each of three rearing tanks and preserved in different labeled bottle samples. The samples were collected daily started from $5 \mathrm{dph}$ until $10 \mathrm{dph}$. After 10 $\mathrm{dph}$, larval samples were taken periodically every other day until the end of this larval rearing (20 dph).

\section{Double Staining Methods}

Vertebral morphogenesis assay was done using double staining methods by Potthoff (1984) with some modification for marine larvae samples by Aslianti (2004). This method has seven steps including fixation, dehydration, cartilage staining, neutralization, bleaching, bone staining, and preservation. With this method, vertebral staining could be performed in a single process, cartilage staining by alcian blue solutions and bone staining by alizarin red solutions.

\section{Vertebral Analysis}

The primary parameter of this study was vertebral morphogenesis description using visual and measurement assays. The visual assay was done by taking pictures of the stain- 
ing samples. The highest percentage of profile larval condition was used for data of morphogenetical larvae. This observation was done by using Nikon Eclipse E1000 microscope with 2-10x magnifications and the picture was taken by using ACT- 1 progam. Larvae were measured by using Olympus SZH- ILLB microscope with $7.5 x-64 x$ magnifications equipped with micrometer. This measurement consist of total length ( $T L)$, vertebral length $(\mathrm{VL})$, length of vertebral segment (LVS), and total of vertebral segment (TVS). The periods from cartilage become bone and deformity that occurs during the study was also noted.

The secondary parameter of this study were growth (total length and body weight) every three days, survival rate at the end this study and water quality analysis during this study. Water quality measurement was done periodically every five days including temperature, salinity, $\mathrm{pH}$, nitrite, and ammonia. The collected data was analized descriptively.

\section{RESULTS}

\section{Vertebral Morphogenesis of Cobia Larvae}

With double staining methods (Phottoff, 1984) could be indicated that cobia larvae had cartilage phase absorbing blue color and had bones phase absorbing red color in their spine. Some other spines, i.e vertebral, maxilla, mandible, pectoral fin, dorsal fin, ventral fin, and caudal fin were composed by calcium and marked by blue color. The vertebral morpho- genesis of cobia larvae was started at $5 \mathrm{dph}$ and transform to pre-cartilage phase until 10 dph (Figure 1).

The vertebral of cobia began structured and segmented on $12 \mathrm{dph}$ up to $16 \mathrm{dph}$ (Figure 2 ). In these periods, the vertebral started cartilage phase. The blue color from alcian blue was absorbed into the vertebral and spines. On $16 \mathrm{dph}$, the spines in larvae body was performed completely and vertebral were ready to transform become bones.

The blue color in vertebral samples started to change into red color absorbing alizarin red at $18 \mathrm{dph}$. This indicated that vertebral entered to bones phase. This color change occurred in vertebral, spines on vertebral, spines of dorsal fin, and spines on ventral fin (Figure 3 ). When vertebral became bones, the segment looked completely separated, the length was clearly seen, the segment number was no longer increase and could be counted. The vertebral changed into red color perfectly on $20 \mathrm{dph}$.

The measurement and description data of vertebral development collected during this study were shown in Table 1 . The vertebral measurement could not be counted from $5 \mathrm{dph}$ until $10 \mathrm{dph}$ because the vertebral has not been formed and still at pre-cartilage phase. The vertebral length (VL), length of vertebral segment (LVS), and total of vertebral segment (TVS) could be counted from $12 \mathrm{dph}$. The data were collected from the dominant of sample larval conditions.
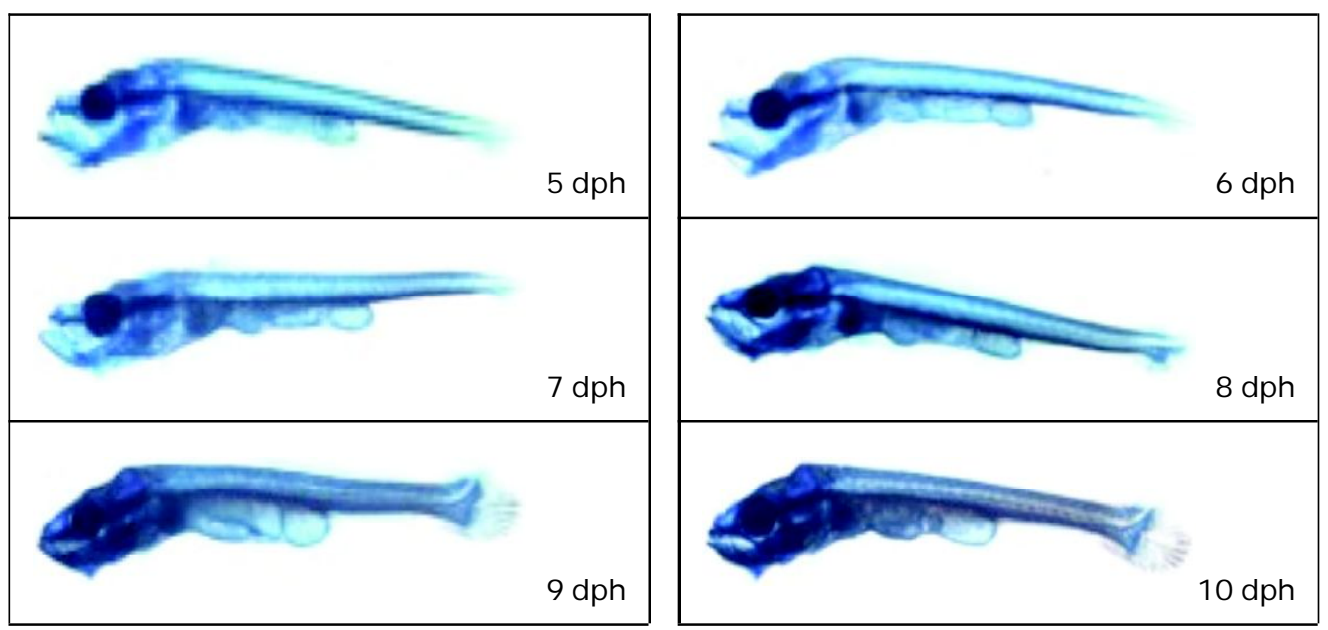

Figure 1. Pre- cartilage formation of cobia larvae 

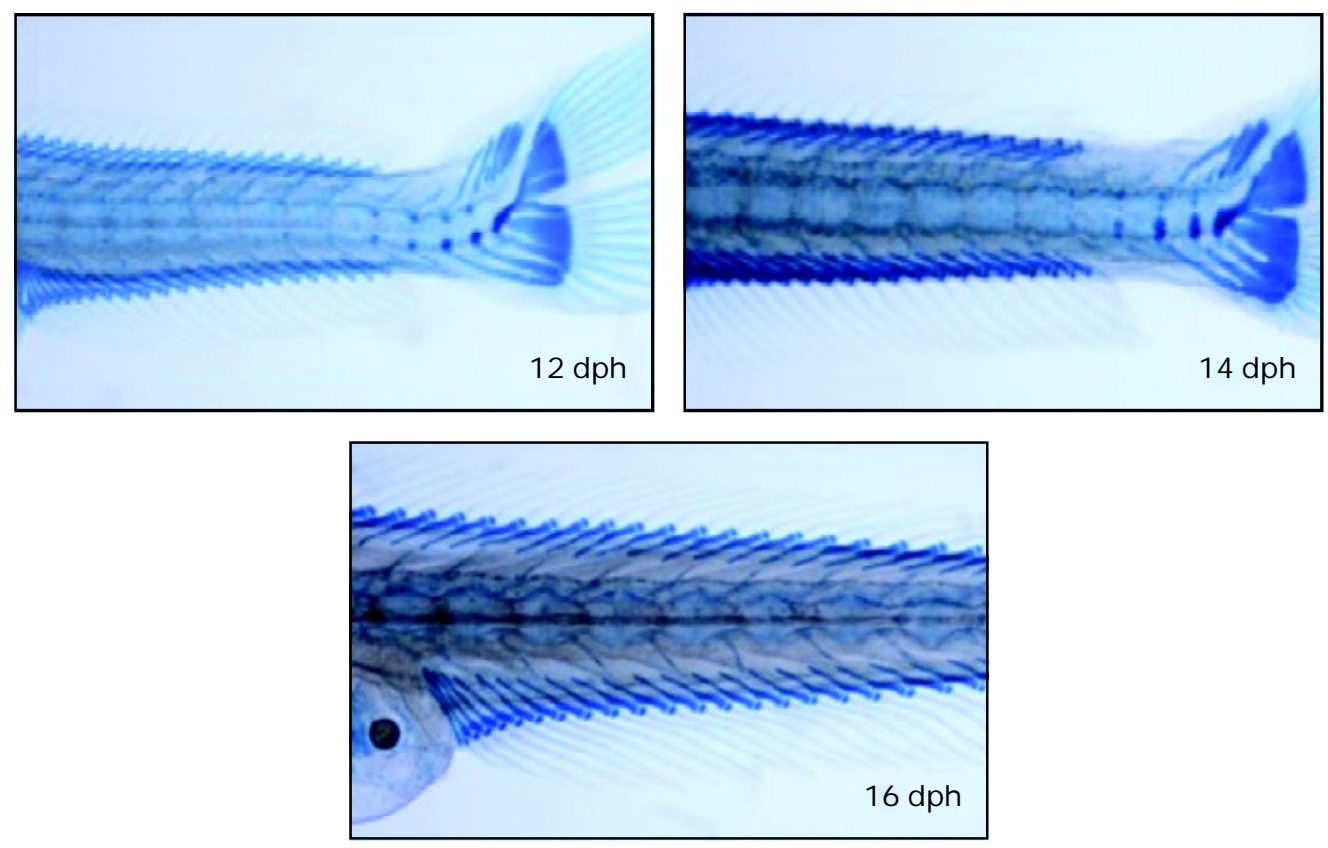

Figure 2. Cartilage phase formation of cobia larvae
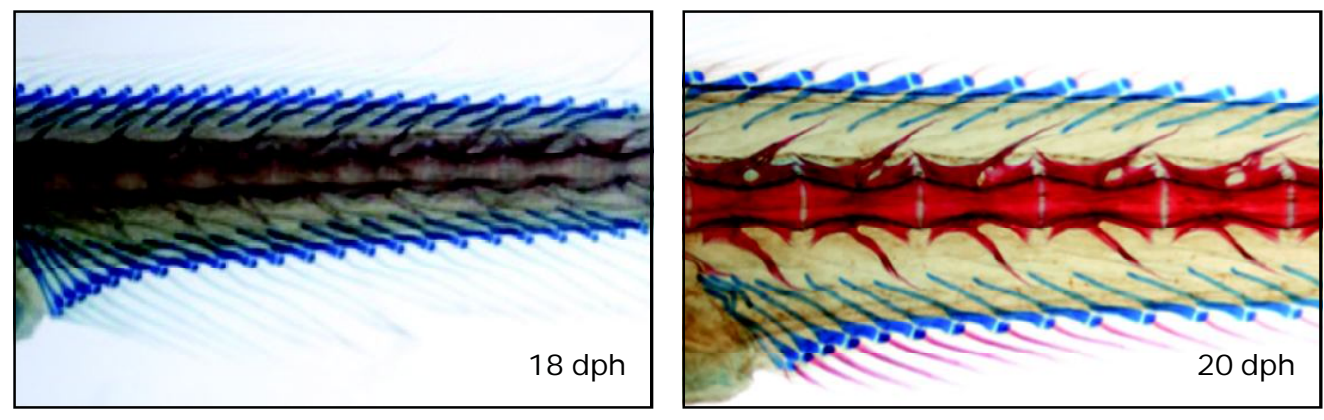

Figure 3. Bones phase formation of cobia larvae

\section{Growth and Survival of Cobia Larvae}

The growth value, including total length, and body weight are presented in Table 2 . The highest total length at the end of this study was performed in first tank $(32.2 \mathrm{~mm})$, than in the third tank $(27.4 \mathrm{~mm})$ and the lowest of total length was performed in second tank $(24.4 \mathrm{~mm})$. This chart was inversely correlated with the survival rate at the end of this study. The highest survival rate was gain at second tank (17.91\%), followed by the third tank (10.16\%), and the lowest was in the first tank $(8.11 \%$. The body weight measurement was showed in Table 2 .

\section{Water Quality in Larval Rearing Media}

Water quality observations showed a relatively stable value and normal throughout this study. Values of some parameters are presented in Table 3.

\section{DISCUSSION}

Marine fish start to develop on the first day after hatching. They undergo important functional and morphological changes during the larval period. A fish's skeleton is composed of cartilage or bone. Basically, the skeleton provides a foundation for the body and the fins, 
Study of vertebral morphogenesis of cobia larvae ... (Afifah Nasukha)

Table 1. Description of vertebral morphogenesis of cobia larvae

\begin{tabular}{|c|c|c|c|c|}
\hline DPH & $\mathbf{L}$ & LVS & TVS & Description \\
\hline 5 & - & - & - & $\begin{array}{l}\text { The vertebral has not yet formed but there } \\
\text { are composed by calcium (pre-cartilage) }\end{array}$ \\
\hline 6 & - & - & - & $\begin{array}{l}\text { The vertebral has not yet formed but the } \\
\text { arrangement of calcium was more apparent } \\
\text { (pre-cartilage) }\end{array}$ \\
\hline 7 & - & - & - & $\begin{array}{l}\text { The dorsal, pectoral, ventral, and caudal } \\
\text { fins were simply formed. The calcium } \\
\text { arrangement was more apparent (pre- } \\
\text { cartilage) }\end{array}$ \\
\hline 8 & - & - & - & $\begin{array}{l}\text { The fins are formed. The caudal fin was } \\
\text { started to curve. The maxilla, mandibulla, } \\
\text { and operculum bones are clearly seen. The } \\
\text { calc ium on vertebral start to enter cartilage } \\
\text { proc ess (pre-cartilage) }\end{array}$ \\
\hline 9 & - & - & - & $\begin{array}{l}\text { The curve on caudal fins are perfectly } \\
\text { complete. The vertebral bec ame cartilage. } \\
\text { The pre spines on vertebral start to } \\
\text { apparent (pre-cartilage) }\end{array}$ \\
\hline 10 & - & - & - & $\begin{array}{l}\text { The cartilage from all spines and vertebral } \\
\text { are formed. The pre spines on vertebral and } \\
\text { body fins are start to apparent (cartilage) }\end{array}$ \\
\hline 12 & $14.58 \pm 1.35$ & $0.70 \pm 0.04$ & 24 & $\begin{array}{l}\text { The vertebral start to segmentation } \\
\text { progress. The pre spines on vertebral and } \\
\text { body fins clearly apparent (cartilage) }\end{array}$ \\
\hline 14 & $10.27 \pm 0.67$ & $0.72 \pm 0.07$ & $24-25$ & $\begin{array}{l}\text { The vertebral has been in segmentation } \\
\text { progress. The segments are formed } \\
\text { rounded and still fused. The pre spines on } \\
\text { vertebral and body fins clearly apparent } \\
\text { (cartilage) }\end{array}$ \\
\hline 16 & $13.00 \pm 0.71$ & $0.75 \pm 0.06$ & $24-26$ & $\begin{array}{l}\text { The vertebral segment was clearly } \\
\text { separated and there are section between } \\
\text { them. The cartilage was formed perfectly in } \\
\text { all vertebral and spines (cartilage) }\end{array}$ \\
\hline 18 & $14.20 \pm 0.84$ & $0.85 \pm 0.07$ & $25-26$ & $\begin{array}{l}\text { The cartilage on vertebral and the spines } \\
\text { start to changing become bones (pre bones) }\end{array}$ \\
\hline 20 & $20.20 \pm 3.90$ & $0.91 \pm 0.11$ & $25-26$ & $\begin{array}{l}\text { The cartilage on vertebral and the spines } \\
\text { start to changing become bones. The } \\
\text { vertebral segment had formed completely } \\
\text { (bones ) }\end{array}$ \\
\hline
\end{tabular}


Indonesian Aquaculture Journal Vol.7 No.2, 2012

Table 2. Growth value (total length and body weight) of cobia larvae

\begin{tabular}{cccccc}
\hline & \multicolumn{2}{c}{ Total length from each tank $(\mathbf{m m})$} & \multicolumn{2}{c}{ Average of } \\
\cline { 2 - 6 } DPH & $\mathbf{T - 1}$ & $\mathbf{T - 2}$ & $\mathbf{T - 3}$ & $\begin{array}{c}\text { Total length } \\
\mathbf{( m m )}\end{array}$ & $\begin{array}{c}\text { Body weight } \\
\mathbf{( m g )}\end{array}$ \\
\hline 1 & 3.73 & 3.73 & 3.73 & $3.73 \pm 0.00$ & $0.00 \pm 0.00$ \\
3 & 4.47 & 4.50 & 4.57 & $4.51 \pm 0.05$ & $0.00 \pm 0.00$ \\
6 & 5.91 & 5.06 & 5.77 & $5.58 \pm 0.46$ & $0.61 \pm 0.16$ \\
9 & 8.22 & 7.51 & 9.03 & $8.25 \pm 0.76$ & $4.72 \pm 0.91$ \\
12 & 12.68 & 10.62 & 12.74 & $12.01 \pm 1.21$ & $12.30 \pm 3.56$ \\
15 & 17.10 & 15.00 & 18.30 & $16.80 \pm 1.67$ & $29.32 \pm 8.28$ \\
18 & 19.80 & 20.30 & 16.90 & $19.00 \pm 1.84$ & $34.81 \pm 2.91$ \\
20 & 32.20 & 24.40 & 27.40 & $28.00 \pm 3.93$ & $74.07 \pm 12.64$ \\
\hline
\end{tabular}

Table 3. Water quality during cobia larval rearing

\begin{tabular}{lccc}
\hline \multirow{2}{*}{$\begin{array}{c}\text { Water quality } \\
\text { parameters }\end{array}$} & $\mathbf{0 8 . 0 0} \mathbf{~ a m ~}$ & $\mathbf{1 2 . 0 0} \mathbf{~ p m}$ & $\mathbf{1 6 . 0 0} \mathbf{~ p m}$ \\
\cline { 2 - 4 } & $29.31 \pm 1.97$ & $29.12 \pm 0.29$ & $30.41 \pm 0.20$ \\
\hline Temperature $\left({ }^{\circ} \mathrm{C}\right)$ & $8.22 \pm 0.12$ & $8.34 \pm 0.11$ & $8.27 \pm 0.10$ \\
$\mathrm{pH}$ & $34 \pm 0.00$ & $33.44 \pm 1.51$ & $34.22 \pm 2.22$ \\
Salinity (ppt) & $6.22 \pm 0.37$ & $6.53 \pm 11.76$ & $5.70 \pm 0.44$ \\
Dissolved oxygen (mg/ L) & $3,946.67 \pm 2,163.99$ & $5,820 \pm 6,715.21$ & $2,333.56 \pm 2,072.94$ \\
Light intensity (lux) & & $0.219 \pm 0.168$ & \\
$\mathrm{NH}_{3}(\mathrm{mg} / \mathrm{L})$ & & $0.054 \pm 0.070$ & \\
$\mathrm{NO}_{2}(\mathrm{mg} / \mathrm{L})$ & & & \\
\hline
\end{tabular}

encases and protects the brain and the spinal cord, and serves as an attachment for muscles. It contains three principal segments: skull, vertebral column, and fin skeleton (Moyle $\&$ Cech, 1992). Morphogenesis of vertebral larvae were occurs in the hatching days until 20 $\mathrm{dph}$. The development of cobia larvae vertebral were consists of three phases, which are pre- cartilage phase, cartilage phase, and bones phase (Table 1).

Pre- cartilage phase on cobia larvae began on 5 dph until $10 \mathrm{dph}$ (Figure 1). In this phase, vertebrae were seen as the longitudinal structure that arranged by calcium and absorbed the blue color. The other bone candidate and body spines were not formed yet.

Increasing with the age, the absorption of blue color was looked even thicker in vertebral and body spines (Figure 2). This indicated that cartilage and body spines were formed and sturdy became cartilage. Vertebral started to extend, the segments, and vertebral spines are forming. The fins of cobia body, i.e. dorsal fin, pectoral fin, ventral fin, and caudal fins appeared, and started to develop. The operculum bones, maxilla, and mandible also were formed even sturdier. This cartilage phase occurred on the seventh day after pre-cartilage phase on 10-16 dph. On the sixteenth, the whole bones of cobia larvae was completely transformed into cartilage and looked like their juveniles biological shape.

Starting from $18 \mathrm{dph}$, the vertebrae samples absorbed the alizarin red and turned into red color, followed by it spines (Figure 3). The vertebrae segment was clearly completed and the ligament between it segments were clearly seen. Total of segment was 25- 26 from each of larval vertebrae. 
One of the main factors that influenced the development of larval marine fish vertebrae is the nutrient of feeds were provided during rearing periods. Protein (Committee of Animal Nutrition, 2003), vitamins (Zambonino et al., 2005), and nine kinds of essential mineral which is $\mathrm{Ca}, \mathrm{P}, \mathrm{Mg}, \mathrm{Zn}, \mathrm{Fe}, \mathrm{Cu}, \mathrm{Mn}, \mathrm{I}$, and Se (Lall, 2003) are the most important nutrient that has a primary function in the formation and the maintenance in fish vertebral.

During this study, from all collected samples, there were no vertebral abnormalities (deformity). Some of the deformities are usually found in other marine fish larvae such as slow growth and lordosis in the red sea bream larvae (Kitajima et al., 1994) in (Aslianti, 2005), kyphosis, scoliosis, and platyspondyly (shortening and thinning of the spine) (Lall, 2007), were not found in cobia larval samples. This indicated that larval rearing in this study could support growth and development of the larvae.

This study showed that vertebral development were in the same line with body development on cobia larvae. Figure 4 shows the average growth of cobia larvae including total length and body weight from all collected samples. This total length pattern was still normal as exponential length curve meaning that the larval growth was still rapid as cobia's nature morphology. On 20 dph, cobia larvae were perfectly become juveniles. As seen from total length, body weight and body morphology that similar to their adults shapes.
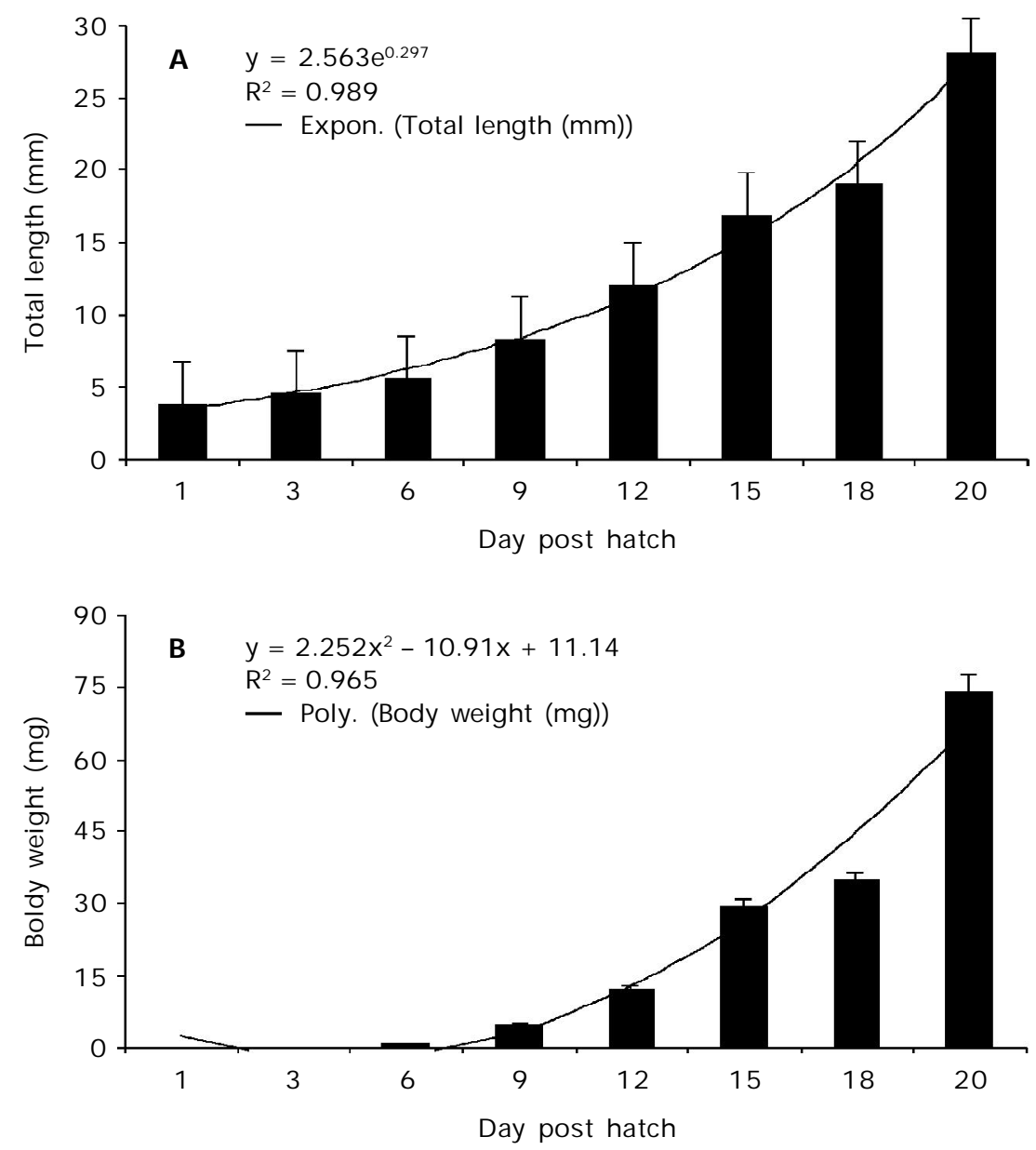

Figure 4. Average growth of cobia larvae after hatching (1 dph) until the end of larval rearing (20 dph). Total length (A) and body weight (B) 
The fish growth was influenced by several factors, i.e biological character of fish, the quality and quantity of feed and water quality of the culture media (Effendie, 1975). Haryanti et al. (1994) reported that appropriate feeding, both size and type, amount and time of feeding of the nutrients they contain and will greatly affect the growth, survival rate, and the ability of larvae to prevent disease.

The cobia survival rate at the end of this study noted that tank- 2 (17.91\%) was higher than on tank- $3(10.16 \%$, and tank- 1 (8.11\%). This result of survival rate was in contrast with the result of total length data from three tanks (Table 2). The higher survival rate was followed by the smallest total length from rearing tank and the lowest survival rate was followed by the tallest total length from rearing tank. Pangni (2008) observed that in high larval density, the larger individuals were seen to exhibit highest swimming activities and waiting in feeding area behaviors both before and during feeding. Moreover, these larvae spent more time eating. In contrast, the smallest were eating from the bottom of the tanks. Adding by Bjoernsson (1994) that under crowded conditions at higher stocking density in rearing tank, fish suffer stress resulting from aggressive feeding interaction, eat less, and growth retardation.

However, the average of this survival rate in this study was $12.06 \%$ This rate was close with other study in cobia larval rearing, i.e. survival rate $11 \% 21 \%$ in study of intensive larval rearing by Smith (2007), survival rate $17.2 \%$ $19.5 \%$ in study of various temperatures by Bennetti (2008), and survival rate $12.7 \pm 0.9 \%$ in study of various stocking density by Hitzfelder et al. (2006).

From analyzed water quality (Table 3 ), it showed that these parameter were stable and in to normal range qualified for larval rearing management. It was proven from the larvae metabolism and growth that increasing and the larvae mortality rate that under control during this study. Nearly every aspect of early fish development is affected by temperature (Alderdice \& Velsen, 1978; Blaxter, 1992). It is well known that temperature has important effects on yolk utilization, starvation, feeding success, early survival, and larvae growth (McGurk, 1984; Fukuhara, 1990).

Water quality in larval rearing media can be dramatically decreased in the fast- growing fish species such as cobia because of the high rate of metabolism. But in the early stadia larval development, the role of metabolic waste can be ignored considering the larval biomass is still low. Water quality degradation was caused by residual natural feed such as Nannochloropsis sp., rotifer and artificial feed which were not consumed by the larvae (Bennetti et al., 2008). These conditions need special handling such as siphon on tank bottom and changing water level according to age and larval development.

\section{CONCLUSION}

This study has shown that the rapid growth of cobia larvae was in line with vertebral development. The vertebral development started on 5- $10 \mathrm{dph}$ at pre- cartilage phase, 12- $16 \mathrm{dph}$ at cartilage phase, of cobia was completely become bones within 18- 20 days larval rearing with optimum rearing condition and optimum feeding. Understanding this vertebral morphogenesis is helpful to enrich the information about the biology and psychology of larval growth in hatcheries. The best larval rearing techniques should be based on their natural behaviors.

\section{ACKNOWLEDGEMENT}

The authors would like to thanks to all of member of marine larval rearing team especially Agus Supriyatna, Muslim Romdlianto, and Dedy Rochaniawan for helping in larval rearing also Siti Zuhriyyah Musthofa for helping in vertebral staining procedure.

\section{REFERENCES}

Anonymous. 2012. All about Cobia. http:// www.marinefarmsbelize.com/about cobia. html. Accessed on 24 April 2012; $08.30 \mathrm{am}$.

Arnold, C.R., Kaiser, J.B., \& Holt, G.J. 2002. Spawning of cobia Rachycentron canadum in captivity. Journal of The World Aquaculture Society, 33(2): 205- 207.

Aslianti, T. 2004. Evaluasi kualitas benih kerapu macan, Epinephelus fuscoguttatus produksi beberapa hatcheri di Bali berdasarkan pengamatan pertumbuhan tulang belakang. Fakultas Teknologi Kelautan dan Perikanan. Universitas Hang Tuah, Jurnal Perikanan, I(2): 56- 62.

Aslianti, T. 2005b. Penentuan abnormalitas larva beberapa jenis ikan laut produk hatchery melalui pengamatan pertumbuhan 
tulang belakang sebagai indikator kualitas benih. Jurusan Perikanan dan Kelautan. Fakultas Pertanian. Universitas Gadjah Mada. Prosiding Seminar Nasional Tahunan Hasil Penelitian Perikanan dan Kelautan, p. 120- 126.

Benetti, D.D., Sardenberg, B., Welch, A., Hoenig, R., Orhun, M.R., \& Zink, I. 2008. Intensive larval husbandry and fingerling production of cobia Rachycentr on canadum. Aquaculture, 281: 22- 27.

Benetti, D.D., Orhun, M.R., Zink, I., Cavelin, F.G., Sardenberg, B., Palmer, K., Denlinger, B., \& Bacoat, D. 2010. Aquaculture of cobia (Rachycentron canadum) in Americas and The Carribean. Florida Aquaculture Publications. Florida USA, p. 57- 77.

Blaxter, J.H.S. 1992. The effect of temperature on larval fishes. Netherland Journal of Zoology, 42: 336- 357.

Bjoernsson, B. 1994. Effect of stocking density on gowth rate of halibut (Hippoglossus hippoglossus L.) reared in large circular tanks for three years. Aquaculture, 123: 259- 271.

Chou, R.L., Su, M.S., \&Chen, H.Y. 2001. Optimal dietary protein lypid levels for juveniles cobia (Rachycentron canadum). Aquaculture, 193: 81- 89.

Committee on Animal Nutrition Board on Agriculture National Research Council. 1993. Nutrient Requirements of Fish. The National Academic Press. Washington D.C., 128 pp.

Effendi, H. 2003. Telaah kualitas air bagi pengelolaan sumber daya dan lingkungan perairan. Penerbit Kanisius. Yogjakarta, 258 pp.

Fukuhara, O. 1990. Effects of temperature on yolk utilization, initial gowth and behaviour of unfed marine fin fish larvae. Marine Biology, 106: 169- 174.

Haryanti, Ismi, S., \& Khalik, A. 1994. Studi penggunaan pakan mikro dan alami dengan perbandingan berbeda dalam pemeliharaan larva udang windu, Penaeus monodon. Jurnal Penelitian Budidaya Pantai, 10(1): 35- 47.

Hitzfelder, G.M., Holt, G.J., Fox, F.M., \& McKee, D.A. 2006. The effect of rearing density on growth and survival of cobia (Rachycentron canadum) larvae in closed resirculating aquaculture system. Journal World Aquaculture Society, 37(2): 204- 209.

Kaiser, J.B. \& Holt, G.J. 2005. Spesies ProfileCobia. Southern Regional Aquaculture Cen- ter Publication. No. 7202, Mississippi, USA, $6 \mathrm{pp}$.

Lall, S.P. 2007. Comparative mineral nutrition of fish: sources and requirements. Academic Press, San Diego, CA, USA, p. 387391.

Liao, I.C., Su. H.M., \& Chang, E.Y. 2001. Techniques in finfish larviculture in Taiwan. Aquaculture, 200: 1- 31.

Moyle, P.B. \& Cech, J.J. 1992. Fishes: An introduction to ichthyology. Prentice hall, Englewood cliffs, New Jersey, 560 pp.

Pangni, B.C. Atsé* \& Kouassi, N.J. 2008. Effect of stocking density on growth and survival of the African catfish Chrysichthys nigodigitatus, Claroteidae (Lacépède 1803) larvae in circular tanks. Lifestock Research for Rural Development, 20(7): 9.

Potthoff, T. 1984. Clearing and Staining Techniques. In Moser, H.G., Richards, W.J., Cohen, D.M., Fahay, M.P., Kendall, A.W.Jr., \& Richardson, S.L. (Eds.) Ontogeny and Systematics of fishes. Am. Soc. Ichthyol. Herpetol., Spec. Publ., 1: 35- 37.

Priyono, A., Slamet, B., Supii, A.I., \& Asmanik. 2006. Pematangan gonad calon induk ikan cobia (Rachycentron canadum) dengan manajemen pakan, pengamatan perkembangan telur dan larva. Laporan tahunan DIPA tahun anggaran 2006. Balai Besar Riset Perikanan Budidaya Laut, Gondol.

Priyono, A., Slamet, B., Supii, A.I., \& Asmanik. 2007. The successful research on breeding and production of Cobia (Rachycentron canadum). Breeding Genetik. Pusat Riset Perikanan Budidaya, Kementerian Kelautan dan Perikanan. Jakarta, p. 169.

Pyng, Y.S., Fu, K.Y., \&Yang, T. 2008. Cobia Culture in Taiwan. Department of Aquaculture, National Pingtung University of Science and Technology. Fish Breeding Association, Republic of China.

Santosa, H., Asmanik, Sukadi, Purnomo, \& Slamet, S. 2009. Rekayasa teknologi pematangan gonad, pemijahan, dan pemeliharaan larva/ benih ikan cobia (Rachycentron canadum). Laporan Tahunan. Balai Besar Pengembangan Budidaya Laut, Lampung. Direktorat Jenderal Perikanan Budidaya. Kementerian Kelautan dan Perikanan.

Saputra, B., Minjoyo, H., \& Nasution, L.M. 2010. Budidaya cobia (Rachycentron canadum) komoditas unggulan yang belum banyak dikenal. Prosiding Forum Inovasi Teknologi Akuakultur 2010, p. 367- 371. 
Indonesian Aquaculture Journal Vol.7 No.2, 2012

Smith, T. 2007. National initiative for aquaculture development and fisheries enrichment of cobia (Rachycentron canadum). National Marine aquaculture initiative. Aqua.Noaa. Gov.pdf/nmai/cobia_smith_06.pdf.

Su, M.S., Chien, Y.H., \& Liao, I.C. 2000 . Potential of arine age aquaculture in Taiwan : Cobia culture. In : Cage aquaculture in Asia, Liao, I.C. \& Lin, C.K. (Eds.). Asian Fisheries Society, Manila Philippines and World Aquaculture Society, South East Asian Chapter, Bangkok, Thailand, p. 97-106.

Sun, L., Chen, H., \& Huang, L. 2006. Effect of temperature on growth and energy bud- get of juvenile cobia (Rachycentron canadum). Aquaculture, 261(3): 872-878.

Xan, L. 2005. Marine Finfish: Advances in the seed production of Cobia in Vietnam. Research Institute for Aquaculture No I, Vietnam. Published in Network of Aquaculture Centres in Asia- Pasific.

Zambonino, J., Chantal, C., Laure, V., \& Gisbert, E. 2005. Nutrition, Development and Morphogenesis in Fish Larvae: Some Recent Developments. Aqua Feeds: Formulation \& Beyond, 2(1): 1- 5 . 